\title{
DESTINATIONS AND TOURISTIC FLOWS IN YOUTH TRAVEL
}

\author{
Moisă Claudia, Lecturer PhD Student, claudiapatrut@yahoo.com \\ “1 Decembrie 1918” University, Alba - Iulia, Romania
}

\begin{abstract}
Many experts in the tourism industry think youth travel is the fastest growing market segment, and the previsions of the World Tourism Organization estimate that in the near future youth travel will tote up $25 \%$ of the worldwide tourism market. On one hand, this phenomenon can be explain through the cultural motivation of the young people in practicing tourism, and on the other, through the relatively low or acceptable costs of transportation, especially for the youth in well developed countries.
\end{abstract}

More and more young people travel abroad for their vacation, to visit their friends or relatives, to study, for bussiness or for other reasons. For many of them these travels represent their first incursion in foreign countries and are a real adventure.

Seen in its dynamics, youth travel is on an ascending path. Like the main indicators of tourist traffic prove, this evolution is due to factors of general or specific influence, that result in the manifestations of certain trends, like: the increase of the number of students worldwide, the increase of the population's income, new touristy destinations, etc.

The global demographic trends indicate that youth travel is a market segment in continuing development. The young population grows constantly and a larger number of this population manifests a desire to travel (partially determined by the unprecedented growth of global communications through the Internet). Statistics show that these young people travel much more often, further from home and at a younger age than the previous generations.

In the next 25 years, an ageing of the population is foreseen, and in 2025 the number of people over 65 years old will double. Still, the glob's population will rise, but in a slower rate than the one in recent past. According to the same demographic trends, in the next two decades the young population (ages below 15 years old) will rise up to $6 \%$, and the number of kids with ages below 5 years old will rise up to $5 \%{ }^{1}$

A special interest for the development of youth travel is represented by the worldwide increase of the annual income. This trend of economic development of certain countries in a faster rate than the demographical growth will have implications in all the segments of tourism, including youth travel. At the same time, recent statistics prove that three regions of the world are responsible for the largest part of the revenues in international youth travel: Europe, North America and Asia. About 60 to $70 \%$ of the young Europeans have traveled abroad in the last years, bringing the total to 52 million young people. Out of the European countries, the most important generators for youth travel are the Scandinavian countries, while the Mediterranean and eastern European countries are the ones with the fastest increase. North America (Canada and USA) generates a total number of departures abroad of approximately 2 million less than the total number of 35 million young people. Japan is the country that occupies the first place in Asia, with approximately 3 million travels abroad annually. $^{2}$

Another trend in youth travel is the development of new touristy destinations. Europe is the battle field for this market, because lately the number of countries with specific youth

\footnotetext{
${ }^{1}$ US Census Bureau, World Population Profile: 1998 - Highlights, 1998

${ }^{2}$ B.I.T.S Seminar, 2001.
} 
travel destinations almost doubled, and destinations like Brazil, Taiwan and Costa Rica are now on the tourist map. Experts expect o continuous increase of the number of young people that work during the summer to pay for their travel expenses. Countries like England and Australia, which are the favorite destinations for young tourists, capitalize this growing trend through an aggressive and flexible marketing of the work and travel opportunities.

Considering the economic and social status of young people and the necessity to support their education process, a process that also includes traveling, youth travel is considered an important component of social tourism.

From this perspective, the development of youth travel in European countries is a major concern for each country and for international organizations that work in the field of youth travel and social tourism.

Considering the international developments, in our country the analysis of the most important trends in youth travel has become a necessity. In this context, in Romania the strategic objectives in the development of youth travel take into account the following: increasing youth travel by attracting disadvantaged young people, expanding programs for training and perfecting young people for professions in tourism, involving NGO's in the administration and management of tourist resources, providing tourist information of interest to the youth, setting up tourist events with an educational purpose, developing the system for youth cards, etc.

It is difficult to indentify the main countries that constitute a travel destination. While statistics for international arrivals are very well documented by the W.T.O. (World Tourism Organisation) and by the majority of national tourism organisations, there are very few data about the age of the travellers. The favourite destinations of the youth must be defined by taking into account the worldwide trends in youth travel and the strategy that each country has for its tourism.

According to the W.T.O., Europe and America are the most sought after destinations by the worldwide youth, but despinde this, destinations like Asia, Africa and the Middle East have a growing market share.

According to the 2003 International Student Travel Confederation (I.S.T.C) and Association for Tourism and Leisure Education's (A.T.L.A.S.) study regarding youth travel „Today's Youth Travellers: Tomorrow's Global Nomads. New Horizons in Independent Youth and Student Travel" in their „tourist career" youth and students visited many regions all over the world, more than half visited Northern and Southern Europe and over $40 \%$ traveled through North America and Western Europe. Less developed regions have also been visited: 18\% visited Central America, 16\% Southern Asia and 13\% Australasia ${ }^{3}$.

The favourite regions for the latest major travel of the youth have been Northern Europe (30\%), Southern Europe (16\%), North America (16\%) and Western Europe (8\%), with a considerable number of visits to South-Eastern Asia and to Australasia (see chart no. 1)

\footnotetext{
3 Sursa: Richards, G., Wilson, J., Today's Youth Travellers: Tomorrow's Global Nomads. New Horizons in Independent Youth and Student Travel, International Student Travel Confederation (ISTC), Amsterdam, 2003.
} 


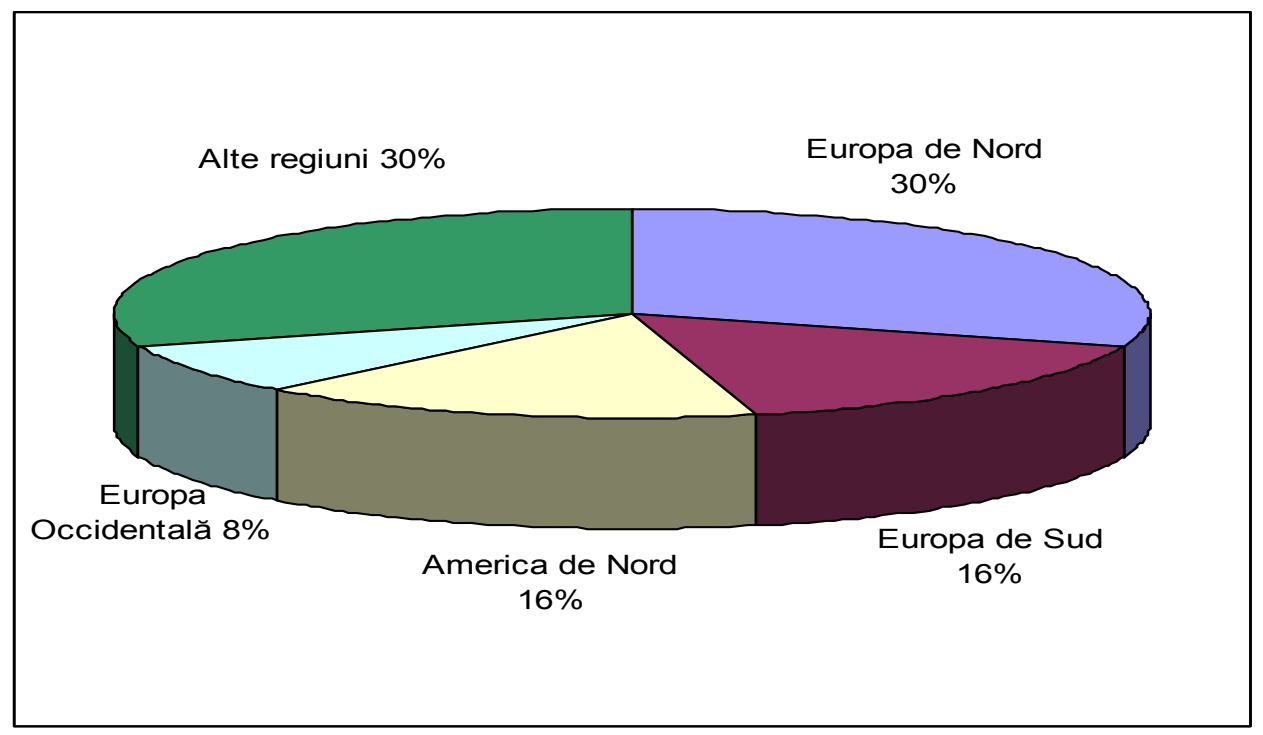

Chart no. 1 Main tourist destinations of the youth for the latest major travel

Source: Richards, G., Wilson, J., Today's Youth Travellers: Tomorrow's Global Nomads. New Horizons in Independent Youth and Student Travel, International Student Travel Confederation (ISTC), Amsterdam, 2003.

Youth usually go back to certain tourist destination, in North America the number of tourists who visit this continent for the first time is lower that the number of tourists who return, and over $70 \%$ European regions are visited several times.

The other tourist regions have a high number of tourists who come for the first time in these countries, especially in the Indian sub-continent (60\% come for the first time), South America, South-Eastern Asia and Australasia (approximately 50\% of the young travelers come here for the first time). These are destinations that must be seen at least "once in a life time".

The regions that are visited by a larger number of tourists with ages over 26 are South and Central Africa (44\%), South and Central America (25\%), the Middle East (21\%) and South-Eastern Asia (20\%). These regions are considered "difficult", and this explains why experienced travelers prefer these destinations, while most young people prefer Europe and North America.

At an intra-regional level, youth visit more different countries, thus: South-Eastern Asia (with 2.4 visited countries), Northern Europe and South America (both with 2.3 visited countries) occupy the first places in youth tourism, and regions like South America (with an average of 9.1 previous travels), China and Japan (8.2), the Indian sub-continent (8.1) and Southern and Central Africa (8) are destinations visited by experienced tourists.

As the tourist's experience grows, people tend to travel more. Thus, the ones who visit Northern Europe have previosly had only five major travels compared to the eight made by the people who visit Australia and the ten voyages of the India tourists. This sustains the ideea of a „tourist career”, Europeans usualy travel first inside Europe, and then to Australasia which is considered their first inter-regional journey and then continue with less known destinations from Asia, Africa and Latin America. 
The tourist market also confronts with a rising competition on the youth travel worldwide market. If western-European markets, like Spain, France, Germany, Great Britain etc. have always been preferred by the youth, between the years 1990 and 2000 new destinations appeared, like Australia and Thailand, and these countries have become leaders in the worldwide youth preferences. After 2000, new "players" like Brazil and England launched youth orientated aggressive promotions which led to impressive results.

The unsafe climate of the last years in certain regions favored some changes in the tourism industry in general and implicitly in youth travel, favoring the development of new destinations. Solitary young travelers chose non-traditional destinations and are known as pioneers in this field, while youth groups tend to be more conservative when choosing a destination. They go to traditional regions, especially for their international travels, and are attracted to new destinations only though an organized event.

A recent study of the Quebec University identified five countries as the main destinations in youth travel: Australia, France, New Zeeland, Thailand and England ${ }^{4}$. All these countries identified young travelers as being an essential market segment, one that brings an important income. Australia, one of the leaders in youth travel, organized aggressive integrated marketing campaigns combined with other initiatives, like introducing a unique visa for the "work \& travel" programs which led to attracting young people to Australasia. New Zeeland and England also attract a large number of solitary young travelers with the help of promotional campaigns like: adventure tourism, cultural tourism, rest and relaxation tourism, offering accommodation services at a reasonable price and flexible work/study/travel programs. France successfully promoted cultural experiences and youth hostels, especially through-out young people in Europe. Thailand makes efforts to promote itself as a safe destination for solitary travelers, stimulating organized groups to discover the Thailand's culture. Experts consider Germany, U.S.A and Canada as important destinations for youth travel, but none of these countries have launched marketing campaigns for the youth travel market.

The fastest growing segment on the youth travel market is represented by the young people who combine traveling with working. The majority of these young tourists take advantage of governmental programs and/or of flexible visas that allow them to work in the countries they visit, with the purpose of covering some of the expenses. United States of America are the favorite destination of most students that work and travel, followed by Australia, England and Canada.

Tourist destinations are influenced by the tourist's country of origin, because it is clear that people usually travel first in their own country. Europe is visited by $50 \%$ of the Europeans, North America by almost $50 \%$ and the other regions by less than $20 \%$. As to the geographical distribution of the international youth travel, there is a concentration in the northern countries that are well developed. There are significant differences in the tourist flows, thus:

Canadians visit Northern Europe and North America, and in Canada there is the highest number of young people who visit Central America.

The main destinations for the people in South Africa are almost exclusively North America and Southern Europe, with the exception of a small number that visits the Indian sub-continent and their native region.

English people usually travel inside Northern and Southern Europe, but also to North America. They are among the youth that visits Central and South Africa, China and Japan.

\footnotetext{
${ }^{4}$ Regroupement Tourisme Jeunesse, Étude de produits et de marchés - Le tourisme jeunesse au Québec, Montréal 2001.
} 
Swedish people visit in a high number destinations from Northern Europe, Southern Europe and North America, but they also visit the south-east part of Asia and Western Europe.

The young people from Hong Kong more and more tend to visit Northern Europe, but also China and Japan. They also record a high number of visits to Australasia because of the geographical proximity of these two regions.

According to statistics, the youth from South Africa have a number of 800.000 travels abroad in the year 2000, from which approximately 600.000 were outside the continent and the main destinations were: Europe (50\%), North America (14\%), Asia (42\%), The Middle East (8\%), Austral Asia (7\%), the islands in the Indian Ocean and Latin America. Australia was the favorite destination in Pacific Asia, followed by India, Thailand, Hong Kong and New Zeeland ${ }^{5}$.

The youth travel market is still predominant in the well developed countries and countries like India, China and the ones in South America have an important potential for the development of this type of tourism, although the development of these markets seems to be slow.

Youth travel is an on going growing market and it's becoming essential for many countries. The majority of the world's countries agree that youth travel will grow in the immediate future and especially on a medium term.

By capitalizing the current and future opportunities, the tourism industry must move fast to recognize young travelers as being a distinct and essential market segment that has an important potential for a long term development.

\section{Bibliography:}

1. Bywater, M., Youth and student travel market, Travel \& Tourism Analyst Vol. 3, 35-50, 1993.

2. Jones, D., Social Tourism in the E.U. - Student \& Youth Travel, European Commission Seminar, Brussels, 2007.

3. Genève, M., Le tourisme, secteur délaissé par les dispositifs européens pour la mobilité des jeunes, Cahier Espaces 77- Tourisme des jeunes, 2003.

4. Keeley, P., International backpacker market, Insights Vol 7, B1-16. 1995.

5. Minciu, R., Economia turismului, ed. a 3-a, Ed. Uranus, Bucureşti, 2004.

6. Minciu, R., Moisă, C., Motivațiile tinerilor în practicarea turismului, Conferința Internațională „Serviciile şi competitivitatea”, Facultatea de Comerţ, ASE Bucureşti, 2006.

7. Moisă, C., Conținutul şi particularitățile turismului de tineret, Conferința Internaţională "Comerț şi competitivitate", Facultatea de Comerț, ASE Bucureşti, 2005.

8. Moisă, C., The global importance of the youth travel, Analele Universității din Oradea, Știinte Economice, Tom XVI, 2007.

9. Richards, G., ISTC/UNWTO Survey on Student and Youth Tourism among National Tourism Administrations/ Organizations, Tourism Market Trends World Overview \& Tourism Topics, 2005.

10. Richards, G., Wilson, J., Today's Youth Travellers: Tomorrow's Global Nomads. New Horizons in Independent Youth and Student Travel, International Student Travel Confederation (ISTC), Amsterdam, 2003.

\footnotetext{
${ }^{5}$ http://www.hotel-online.com/News/PressReleases1998_4th/Oct98_PATAYouth.html
} 
11. Seekings, J., The youth travel market, Travel \& Tourism Analyst Vol 5, 37-55. 1998.

12. ***World Youth Student \& Educational Travel Confederation, The Global Youth, Student \& International Education Market: Research Findings and Representation Activities, 2006.

13. ${ }^{* * *}$ Regroupement Tourisme Jeunesse, Étude de produits et de marchés - Le tourisme jeunesse au Québec, Montréal, 2001.

14. *** WTO, Youth Outbound Travel of the Germans, the British and the French, 2002.

15. http://www.hotel-

online.com/News/PressReleases1998_4th/Oct98_PATAYouth.html 